

\title{
REVIEW
}

\section{Childhood Bronchial Asthma in Nigeria: A Review of the Burden and Challenges of Management Kuti BP}

\author{
Department of Paediatrics and Child Health, Faculty of Clinical Sciences, Obafemi Awolowo University,
} Ile-Ife, Nigeria

Correspondence: Dr BP Kuti, Department of Paediatrics and Child Health, Faculty of Clinical Sciences, Obafemi Awolowo University, Ile-Ife, Nigeria. E-mail: kutitherapy@yahoo.com ;

ORCID - https://orcid.org/0000-0002-4788-4362.

\section{Summary}

Bronchial asthma care professionals all over the world are faced with many challenges in managing children with asthma. This narrative review highlights the burden and specific challenges encountered by Nigerian health care professionals in the care of children with bronchial asthma and attempts to suggest ways of overcoming some of these challenges for optimal bronchial asthma care.

An electronic search of relevant published articles from the year 2000 to date was carried out using appropriate search engines for the following search words and phrases: "asthma in Nigerian children", "childhood asthma in Nigeria", "burden of asthma", "challenges," "prevalence" and "cost of bronchial asthma care."

The findings revealed that childhood bronchial asthma was reported in all the geo-political zones of the country with evidence of the increasing prevalence and male preponderance. Higher prevalence rates were reported in urban settings compared to rural settings and intermittent asthma was the most frequently reported form of the disease in Nigeria. Allergic rhinitis, with or without conjunctivitis were the most common co-morbidities, while respiratory tract infections, exposure to dust and physical exercise were the common triggers. Bronchial asthma was reported to affect school attendance, family finances and the quality of life of children and their caregivers.

Reported challenges of childhood bronchial asthma in Nigeria included ignorance, poverty, stigma and poor adherence to medications by affected children and caregivers; inadequate workforce and suboptimal knowledge of various cadres of health workers and the poor health system as well as little or no availability of standard asthma care facilities at all levels of health care in Nigeria.

Awareness creation, routine training and re-training of all cadres of health workers, provision of basic asthma care facilities and revamping of the health system may assist in overcoming the challenges.

Keywords: Allergy, Bronchial asthma, Bronchoconstriction, Challenges, Inhalation corticosteroids, Nigeria.

\section{Introduction}

Bronchial asthma is described by the Global Initiative on Asthma (GINA) as a heterogeneous disease characterised by chronic inflammation of the small airways and airway hyperresponsiveness to common allergies, in which cells and cellular elements play significant roles. 
[1] Bronchial asthma in children often manifests as recurrent episodic wheezing, breathlessness, chest tightness and cough which vary over time and the disease is often reversible either spontaneously or with the use of medications. [1]

The reported prevalence rates of childhood bronchial asthma in Nigeria vary widely depending on the modality of diagnosis (use of questionnaire vs. lung function assessment), study design (hospital-based vs. community based) and location of study (rural vs. urban). [2] It is believed that $5-10 \%$ of Nigerian school-age children have asthma, with probably another 3$5 \%$ with unrecognised or undiagnosed asthma. ${ }^{22]}$ The International Study of Asthma and Allergic Diseases in Childhood (ISAAC) labelled Nigeria as low to medium prevalence as regards childhood asthma. [3] However, over the last decades, there has been a reported increase in the prevalence rates of asthma in children in Lowand Middle-Income Countries (LMICs) including Nigeria. ${ }^{[4,5]}$

The pathogenetic basis of asthma involves interplay between genetic predisposition and environmental factors. [6] The genetic predisposition in childhood bronchial asthma had been expressed in twin studies in which higher concordance was reported among homozygotic than dizygotic twins. [6, 7] Also, different genetic expressions had been reported in the ways asthmatics response to anti-asthma medications, including short-acting bronchodilators (SABA) and inhaled corticosteroids (ICS). [6] Epigenetic effects of environmental factors modifying the genetic expression of traits concerning bronchial asthma in children, including the study of single nucleotide polymorphism associated with childhood asthma in the genome-wide association studies (GWAS) had been reported. ${ }^{6}$

Therefore, symptoms of asthma occur when a genetically predisposed individual is exposed to allergenic triggers which are carried by antigen- presenting cells via Major Histocompatibility II (MHC II) to naïve T lymphocytes. [8] These cells become committed to the T-helper cells $\left(\mathrm{Th}_{2}\right)$ lineage resulting in the elaboration of $\mathrm{Th}_{2}$-specific inflammatory cytokines, including Interleukin (IL-)-3, IL-4, IL-5, IL-9 and IL-13. [8] These attract and enhance the maturation of inflammatory cells such as eosinophils, mast cells, basophils and plasma cells. These cells then release inflammatory mediators like eosinophils cationic proteins, histamines, resulting in bronchoconstriction, goblet cells hyperplasia, mucous plugging of the small airway lumen and resultant symptoms of bronchial asthma. [8] The roles of IL-17, IL-25 and IL-33 and other mediators which stimulate the low $\mathrm{Th}_{2}$ pathway of inflammation resulting in bronchial asthma symptoms are also being increasingly recognised. [8]

The diagnosis of bronchial asthma in children entails suggestive history, clinical examinations including assessing for the features of comorbidities such as allergic rhino-conjunctivitis, atopic dermatitis, and gastroesophageal reflux disease (GERD). [1, 2,9] Objective demonstration of reversible expiratory airflow obstruction is recommended in initial and follow-up assessment of bronchial asthma in children and is strongly encouraged by both global [1] and national guidelines. [9] Also of importance is the demonstration of airway inflammation, either non-invasively through the measurement of fractional exhaled Nitric Oxide (FeNO) or demonstration of inflammatory mediators in the serum or by bronchoalveolar lavage. [1] Allergic skin tests and other radio-allergic tests are performed to recognise the specific allergen acting as the triggers for the exacerbation of bronchial asthma. ${ }^{[1,8]}$

The heterogeneous nature of childhood bronchial asthma has informed several longitudinal studies to characterise the various phenotypes of bronchial asthma and wheezing observed among 
children. [10-11] Martinez et al [10] described three wheezing phenotypes in preschool children; these include early transient wheezers, persistent wheezers and late-onset wheezers, based on the time course of disease onset. Based on the triggers of acute exacerbation, childhood bronchial asthma has been classified as episodic viral wheezing and those with multiple triggers. [10] Other bronchial asthma phenotypes described among children include obesity-related asthma, asthma triad, and rarely, occupational asthma. ${ }^{[1}$ 9]

\section{Management of childhood asthma}

GINA guidelines entail step-wise management of bronchial asthma in children with careful assessment of disease severity and the commencement of appropriate controller medication often via a spacer device. [1] The comorbidities and triggers of bronchial asthma are also addressed and the caregivers along with the child are given a written asthma action plan to guide further management at home and school.[1] Next, the levels of symptoms control are assessed at the next clinic visit, usually between two and four weeks later. Subsequently, the controller medications are stepped up, continued or stepped down depending on the level of symptoms control at intervals. [1] Recently, precision asthma management is advocated with attention paid to bronchial asthma endotypes which involve classification based on the pathogenic mechanism underlying the disease. ${ }^{[1}$ 12] Therefore, childhood bronchial asthma may be predominantly $\mathrm{Th}_{2}$-driven inflammation or the Th2 low endotypes. [12] This has led to the use of biologics targeted at specific inflammatory mediators and cytokines in severe and difficultto-control cases of bronchial asthma not responsive to high dose ICS. $[1,12,13]$ These include the use of omalizumab approved as anti-IgE medication, mepolizumab as anti-IL-5 agents and dupilumab as anti-IL-4/IL-13 agents. [13] These biologics have specific indications and specifications for use in the management of severe bronchial asthma, particularly when high dose inhaled corticosteroids is unable to achieve adequate control of symptoms. $[1,12,13]$

This review aims to report the recent burden of childhood bronchial asthma in Nigeria including the documented prevalence, associated comorbidities and triggers, other direct and indirect burdens of asthma in children, the challenges of management of this disease and an attempt to proffer solutions to the problems of childhood bronchial asthma management in a developing economy like Nigeria.

\section{Methods}

An extensive literature search was conducted on the subject on Google Scholar, PubMed, Scopus, African Journal Online (AJOL) and other electronic databases, clinical websites and journals. The search strings included "asthma in children," "childhood asthma," "burden of asthma," "epidemiology of asthma in Nigerian children," "cost of asthma in Nigerian," "direct and indirect costs," "challenges," and "Nigeria." The bibliographies of the search outputs were also screened for relevant publications that were missed in the initial search. The selected articles included those published about childhood asthma in Nigeria over the last 20 years (the year 2000 till date). Relevant information was extracted from the identified articles based on the objectives of the study.

\section{Results}

A total of 1606 records were obtained from the electronic databases and other sources. Two hundred and ten duplicated records were removed. Of the remaining 1396 records, 1313 unrelated articles (published among adults only) were excluded. The remaining 73 relevant studies 
were screened by their year of publication, and 15 records were further excluded. Fifty-eight articles were finally selected for this review. The selected studies were categorized into the following subthemes: community and school-based studies, hospital-based studies, studies about healthrelated Quality of Life (QoL) and academic performance of children with asthma, studies about knowledge assessment concerning childhood bronchial asthma, studies about cost implications of asthma care in children and facilities and practice audits. The details of the selection steps of the studies included in the review are highlighted in Figure 1.

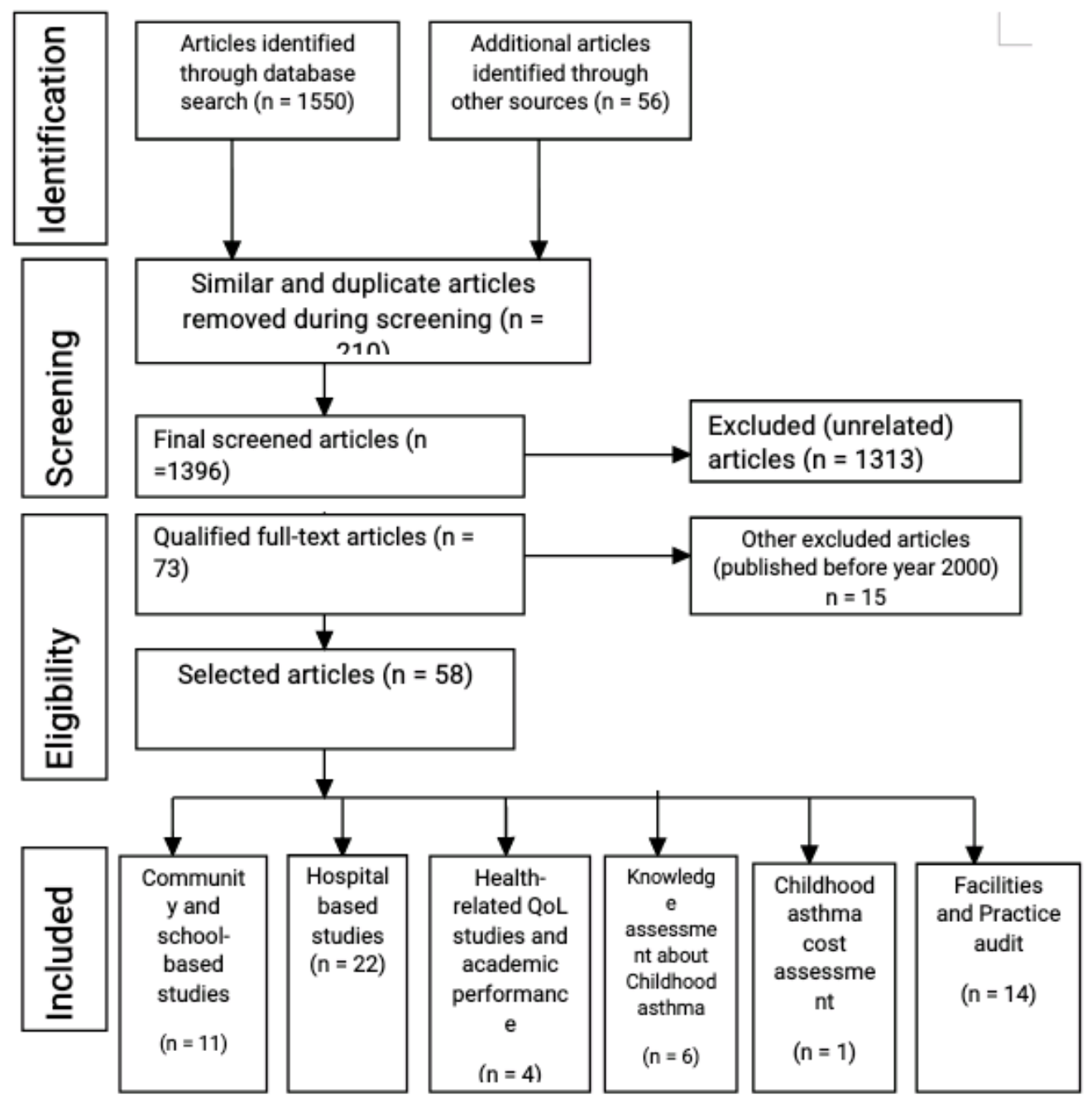

Figure 1: Flow chart of the process of selection of relevant articles

The prevalence and burden of childhood asthma in Nigeria

Community and school-based studies on childhood bronchial asthma in Nigeria estimated the prevalence rates of the disease to range from
$2.2 \%$ to $22.8 \%{ }^{[5,14-23]}$ as shown in Table I. The reviewed studies consistently showed that childhood bronchial asthma was reported from most of the geo-political zones of the country with higher prevalence rates in urban settings 
compared to rural settings. [20-23] Bronchial asthma is probably underdiagnosed and poorly recognised in Nigerian children, particularly in rural settings. [20-23] Combinations of questionnaire-based studies and objective lung function assessment studies in childhood bronchial asthma in schools and communities revealed large proportions $(9.2 \%$ to $28.5 \%)$ of children with bronchial asthma and exerciseinduced bronchoconstriction (which is a surrogate for asthma) were undiagnosed. [20-23]

Table I: Community and School-based studies on childhood bronchial asthma in Nigeria

\begin{tabular}{|c|c|c|c|c|c|c|}
\hline \multirow{2}{*}{$\begin{array}{c}\text { Age } \\
\text { (years) }\end{array}$} & \multirow{2}{*}{$\begin{array}{c}\text { Location } \\
\text { (Ruralurban) }\end{array}$} & \multirow{2}{*}{$\begin{array}{c}\text { Sample } \\
\text { size }\end{array}$} & \multirow{2}{*}{$\begin{array}{c}\text { Prevalence } \\
(\%)\end{array}$} & \multicolumn{2}{|c|}{ Methods } & \multirow[t]{2}{*}{ Studies } \\
\hline & & & & $\begin{array}{c}\text { Questionnaire } \\
\text { s }\end{array}$ & LFT & \\
\hline $6-11$ & $\begin{array}{l}\text { Kano, (U) } \\
\text { Northwest }\end{array}$ & 811 & 12.5 & + & Spirometry & Akhiwu et al 14 \\
\hline $6-17$ & Nationwide & 11395 & 3.1 & + & - & Ozoh et al $l^{15}$ \\
\hline $5-11$ & $\begin{array}{c}\text { Jos (R) } \\
\text { Northcentral }\end{array}$ & 299 & 9.4 & + & Spirometry & Thatcher et al ${ }^{16}$ \\
\hline $6-7$ & $\begin{array}{l}\text { Ibadan (U) } \\
\text { Southwest }\end{array}$ & 1704 & 7.2 & + & - & Falade et $a l^{5}$ \\
\hline $13-14$ & $\begin{array}{l}\text { Ibadan (U) } \\
\text { Southwest }\end{array}$ & 3058 & 16.4 & + & & Falade et al 17 \\
\hline $5-14$ & $\begin{array}{l}\text { Gusau (SU) } \\
\text { Northwest }\end{array}$ & 1064 & 6.0 & + & PFM & Onazi et al ${ }^{18}$ \\
\hline $\begin{array}{c}\text { Adolesc- } \\
\text { ence }\end{array}$ & $\begin{array}{c}\text { Anambra (U) } \\
\text { Southeast }\end{array}$ & 200 & 14.2 & + & - & Ibe and Ele 19 \\
\hline $8-16$ & $\begin{array}{c}\text { Ilesa (R) } \\
\text { Southwest }\end{array}$ & 250 & 9.2 & + & PFM & Kuti et al ${ }^{20}$ \\
\hline $9-17$ & $\begin{array}{l}\text { Ilesa (U\& R) } \\
\text { Southwest }\end{array}$ & 250 & 22.8 vs. 8.5 & + & Spirometry & Kuti et al ${ }^{21}$ \\
\hline $6-21$ & $\begin{array}{c}\text { Aba-Nla, } \\
\text { Eruwa, and } \\
\text { Igbo-Ora } \\
\text { Southwest (R) }\end{array}$ & 1690 & $2.2\left(24.4^{*}\right)$ & + & - & Oluwole et al22 \\
\hline $13-14$ & $\begin{array}{c}\text { Ibadan (U) } \\
\text { Aba-Nla, } \\
\text { Eruwa, and } \\
\text { Igbo-Ora } \\
\text { Southwest (R) }\end{array}$ & 1736 & 8.0 vs. 7.5 & + & - & Oluwole et al23 \\
\hline
\end{tabular}

Characterisation of childhood bronchial asthma in Nigerian hospitals

Table II highlights the summary of characterisation of bronchial asthma in Nigerian children attending specialist clinics in hospitals. [24-30] There was a male preponderance in all the published studies and a majority $(85.7 \%)$ of the studies were conducted in tertiary centres. The reported ages of the children ranged from infancy to 17 years and the presence of bronchial asthma, even among infants and preschool children, were reported. In term of asthma severity, the majority $(85.7 \%)$ of the reviewed studies reported intermittent asthma to be the most prevalent type 
and the persistent type were mostly mild persistent in form. The rarity of severe asthma is common to all the studies across the country. The triggers of childhood bronchial asthma were avoidable ones such as dust, acute respiratory infections, exercise/exertion and fumes. [24-30] Indeed, the use of biomass fuel has been reported to increase the odds of asthma symptoms in rural Nigerian school children. [16, 22]

Table II: Epidemiology, pattern and triggers of bronchial asthma in children attending paediatric chest clinics in Nigeria

\begin{tabular}{|c|c|c|c|c|c|c|c|c|}
\hline $\begin{array}{c}\text { Age } \\
\text { (years } \\
\text { ) }\end{array}$ & Location & $\begin{array}{c}\text { Sample } \\
\text { size }\end{array}$ & M: F & $\begin{array}{c}\text { Pattern of } \\
\text { Severity } \\
\text { Most common } \\
(\%)\end{array}$ & $\begin{array}{c}\text { Co- } \\
\text { morbidities }\end{array}$ & Triggers & $\begin{array}{l}\text { Level of } \\
\text { Symptoms } \\
\text { Control }\end{array}$ & Studies \\
\hline $\begin{array}{c}10 \\
(7-11)\end{array}$ & Enugu & 207 & 1.5 & Intermittent & $\mathrm{AR}, \mathrm{AC}$ & $\begin{array}{l}\text { Dust and } \\
\text { Exercise }\end{array}$ & $69.1 \%$ & $\begin{array}{c}\text { Ayuk et } \\
a^{24}\end{array}$ \\
\hline 4.4 & Sokoto & 78 & 1.4 & $\begin{array}{c}\text { Intermittent } \\
(76.9 \%)\end{array}$ & $\mathrm{AR}$ & - & - & $\begin{array}{c}\text { Garba et } \\
a l^{25}\end{array}$ \\
\hline $\begin{array}{c}7.6 \\
(3.4)\end{array}$ & Lagos & 51 & 1.9 & $\begin{array}{l}\text { Mild } \\
\text { persistent } \\
(47.1 \%)\end{array}$ & $\mathrm{AR}, \mathrm{AC}$ & - & - & $\begin{array}{c}\text { Odusote } e t \\
a l^{26}\end{array}$ \\
\hline $\begin{array}{c}6.4 \\
(3.6)\end{array}$ & Ilesa & 110 & 1.6 & $\begin{array}{c}\text { Intermittent } \\
(82.7 \%)\end{array}$ & $\mathrm{AR}, \mathrm{AC}$ & $\begin{array}{l}\text { RTIs and } \\
\text { Exercise }\end{array}$ & $83.7 \%$ & $\begin{array}{l}\text { Kuti and } \\
\text { Omole }^{27}\end{array}$ \\
\hline $\begin{array}{c}6.8 \\
(4.0)\end{array}$ & $\begin{array}{c}\text { Port } \\
\text { Harcourt }\end{array}$ & 40 & 3.4 & $\begin{array}{c}\text { Intermittent } \\
(87.5 \%)\end{array}$ & - & Cold and Dust & - & $\begin{array}{c}\text { Okoh and } \\
\text { Briggs }^{28}\end{array}$ \\
\hline $\begin{array}{c}8.5 \\
(3.1)\end{array}$ & Benin & 77 & 2.3 & $\begin{array}{c}\text { Intermittent } \\
(62.3 \%)\end{array}$ & - & - & - & $\begin{array}{c}\text { Oviawe } \\
\text { and } \\
\text { Osarogiag } \\
\text { bon } 29\end{array}$ \\
\hline $\begin{array}{c}4.7 \\
(3.0)\end{array}$ & Kano & 70 & 2.5 & $\begin{array}{c}\text { Mild } \\
\text { persistent } \\
(42.9 \%)\end{array}$ & $\mathrm{AC}, \mathrm{AR}$ & $\begin{array}{l}\text { Insecticides } \\
\text { Exercise }\end{array}$ & - & $\underset{30}{\text { Garba et al }}$ \\
\hline
\end{tabular}

AR - Allergic rhinitis; AC - Allergic conjunctivitis; RTIs - Respiratory Tract Infections; M: F - Male-to-Female ratio

Co-morbidities in childhood bronchial asthma

Many co-morbid conditions have been reported in Nigerian children with bronchial asthma. [24-30, 32, 33] Allergic rhinitis, with or without conjunctivitis, was the most reported asthma comorbidity observed in $33.3 \%$ to $84.6 \%$ of the children studied. [24-30] Other reported co-morbid conditions included atopic dermatitis, obesity/overweight; adenoidal hypertrophy and GERD. [24-30, 32] The presence of allergic diseases was reported not to be associated with disease severity but can influence symptoms control. [32] Psychosocial morbidities were described in 25\% of a cohort of children with asthma in a tertiary health facility in Ilorin, Nigeria. [33] These psychosocial morbidities included social impairment, anxiety, feeling of being a burden and interference with daily activities. [33]
Serum Vitamin D, micronutrients levels and bronchial asthma in Nigerian children

Nigerian children with bronchial asthma, like their counterparts from other LMICs ${ }^{[34]}$ and even in developed countries, ${ }^{[35]}$ have been reported to have significantly lower serum 25hydroxyvitamin $\mathrm{D}$ than their age and sexmatched controls without asthma, [36, 37] despite the abundant availability of sunshine in the country. The relatively low serum vitamin D in children with bronchial asthma may also have effects on their cytokine profiles, [38] but was not associated with disease severity and symptoms control. [36, 38] Serum vitamin D levels and bronchial asthma may have a cause-effect relationship. Increased demand for this immunomodulatory vitamin may occur in bronchial asthma; conversely, suboptimal serum 
vitamin D levels may predispose children to asthma and other inflammatory diseases. [36, 38]

Bronchial asthma is associated with inflammation and generation of reactive oxygen and nitrogen species with consequent increased oxidative stress and increased need for antioxidants. ${ }^{[39]}$ Nigerian children with bronchial asthma have been reported to have lower serum micronutrients (zinc and selenium in particular) and lower antioxidants compared to their nonasthmatic controls, [40] and these micronutrient deficiencies may affect disease severity. [40] Conversely, markers of inflammation like high sensitivity C- Reactive Protein (hs-CRP) was observed to be markedly elevated in children with asthma compared to the controls, particularly in those with acute asthmatic exacerbations. [41] This observation calls for a high index of suspicion for micronutrients, antioxidants and vitamin deficiencies among Nigerian children with asthma by care providers. These deficiencies should be suspected and promptly addressed for more holistic asthma care in children in Nigeria and other LMICs.

\section{Acute asthmatic exacerbations in Nigerian children}

Reported studies on exacerbations of childhood bronchial asthma in Nigeria showed that it may be responsible for about $2.9 \%$ to $6.5 \%$ of admissions into Children Emergency Units. [42, 43] There were also reported peaks of exacerbations during the rainy seasons. ${ }^{[42,43]}$ Unfortunately, the levels of knowledge of health care providers in the management of asthma exacerbation appears grossly suboptimal. [44] Fawibe, et al, [44] in a survey of the mode of management of asthma exacerbation among Nigerian doctors in private practice, observed that majority $(83.6 \%)$ were not aware of any guideline, both local and global, hence there was the frequent use of "aberrant drugs" such as antibiotics, mucolytic agents and antihistamines in their treatment schedules. This may even be worse in the rural part of the countries where the diagnosis may not even be correctly made and the disease may be poorly recognised and managed.

Childhood bronchial asthma and school absenteeism Bronchial asthma is a leading cause of school absenteeism in school-age children worldwide including Nigeria. ${ }^{[45-47]}$ Nduagubam, et al. ${ }^{[45]}$ in Enugu, southeast Nigeria, reported that children with bronchial asthma were more likely to be absent from school compared to their counterparts without asthma. Similar findings have been reported in parts of the developed countries. [46, 47] Indeed, childhood bronchial asthma was estimated to be responsible for about 14.4 million school absence days in the US alone in 2008. [46] Prolonged school absenteeism has the potential to affect academic performance and development of children with bronchial asthma. [47]

\section{Childhood bronchial asthma and quality of life}

Studies in Nigeria reported significant low quality of life (QoL) in children with asthma compared to children without asthma. [48-50] The QoL score was significantly affected by disease severity and level of symptoms control; the physical domain of QoL assessment was the most affected. [48-50] Also, female asthmatics were observed to be more affected than their male counterparts. [48-50] The caregivers of children with bronchial asthma were also reported to have low QoL which is related to the severity and control of their children/wards' disease. [50]

Economic implications of childhood asthma in Nigeria- direct, indirect and intangible cost

The "Disability-adjusted Life Years" (DALYs) is a measure of disease burden proposed by the Global Burden of Disease Study (GBD) to quantify years of life lost due to death and/or non-fatal illness or impairment. [51] It is a sum of years of life lost plus years lived with disability (YLDs). ${ }^{[51]}$ Bronchial asthma was the fourteenth highest ranked cause of global YLDs at all ages. [52] Asthma accounted for 15 million DALYs 
which was $1.1 \%$ of the overall global estimate of DALYs/100,000 for all causes in 2015. [52] Global asthma-related costs are high and are classified as direct, indirect and intangible costs. [53] Figure 2 highlights the components and interactions of the direct, indirect and intangible cost of childhood asthma in Nigeria.

A recent report of the cost implications of childhood asthma in Nigeria estimated the annual cost of asthma treatment to be USD162.49, with a cumulative national cost of USD 0.16 billion, which makes up $0.002 \%$ of the national GDP. ${ }^{[54]}$ The direct cost was estimated to account for $50-80 \%$ of the total cost of childhood asthma care. Remarkably, the cost of childhood bronchial asthma care was catastrophic in $18.2 \%$ of the households studied. [54] The high cost of managing childhood bronchial asthma was also reported from developed countries. [55] These costs coupled with indirect and intangible cost (which are often not estimated and not accounted for), make the optimal management of childhood bronchial asthma beyond the reach of the average Nigerian family, if unsubsidised.

\section{Mortality in bronchial asthma}

Bronchial asthma was estimated by the WHO to cause 11,894 deaths in 2017; this was about $0.59 \%$ of the total deaths in Nigeria. [57] The age-adjusted death rate for bronchial asthma was 13.90 per 100 , 000 population. This ranks Nigeria $37^{\text {th }}$ in the world. [56] Childhood death related to bronchial asthma is reportedly rare in Nigeria and has been reported to be more likely among adolescent females, [57] particularly, in situations of poor asthma control, non-usage of inhaled corticosteroids or poor asthma perceptions and treatment. ${ }^{[58]}$ Poor reports of bronchial asthmarelated child deaths in Nigeria may be related to underdiagnosis and under-reporting of the disease, [31] particularly, in rural areas of the country where asthma is often misdiagnosed or mislabelled as other childhood respiratory diseases. [22]


Indirect cost

- Parental/caregiver work absenteeism

- School absenteeism

Intangible cost

Reduced quality of life Limitation of activities Emotional and

psychological effects

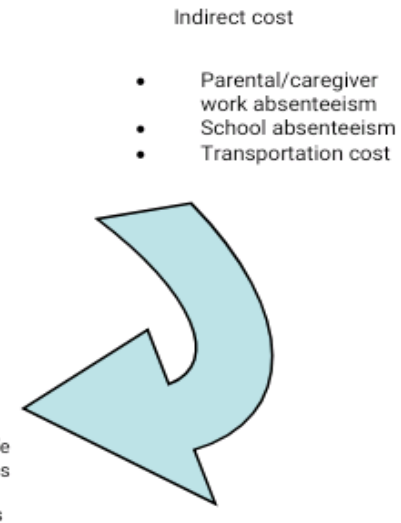

Figure 2: Direct, indirect and intangible cost of Childhood asthma 


\section{Challenges of management of childhood bronchial asthma}

No doubt, asthma care providers in Nigeria, like their counterparts in other LMICs and indeed all over the world face a lot of challenges in the diagnosis, management and follow-up care of bronchial asthma in children. Some of these challenges are shared with the adult physicians and health care providers, ${ }^{58}$ while others are peculiar to the paediatric population. [59] These challenges will be categorised in this review into three: patients and caregivers- related factors, health care providers-related factors and health facilities-related factors.

\section{Patients and caregivers-related challenges Ignorance and misconceptions}

Ignorance and misconceptions about the disease is a major challenge in the management of childhood bronchial asthma in Nigeria and other LMICs. Patients often present late to hospitals, hence the institution of effective management plans are also delayed. This contributes to underdiagnosis and poor recognition of the disease in children. [22, 31] Ignorance and misconceptions abound even among parents/caregivers of children with diagnosed and recognised cases. [60] Studies assessing the level of knowledge of parents/caregivers of Nigerian children with asthma about the disease yielded suboptimal knowledge levels with lots of misconceptions about the disease. [60] Similar results were also reported among teachers in Nigerian schools. [61, 62] The level of knowledge was not associated with parental educational qualifications or social classes, rather it was significantly determined by having had previous instructions about the disease and previous participation in the management of children with asthma. [62] This observation calls for comprehensive and ongoing education of parents, caregivers and school teachers on childhood asthma.
Poverty

Nigeria is a country where the majority of the population live below the poverty line and the major means of health care financing is out-ofpocket payment. [63] These factors affect the management and optimal control of childhood asthma. The low socio-economic class was one of the reasons for poor control of bronchial asthma in a cohort of childhood asthmatics attending a tertiary care asthma clinic in southwest Nigeria. [64] Characterisation of bronchial asthma in children will involve routine lung function assessment, skin, blood and other investigations to detect co-morbidities and triggers. These, coupled with other direct costs of purchase of controller and reliever medications and indirect cost of transportation including intangible cost, make the total cost of adequate management of childhood asthma unaffordable to an average family in Nigeria, if unsubsidised. [54]

Stigma and aversion to using of inhalation devices Caregivers often have lots of misconceptions about the nature, diagnosis and management of childhood asthma. [60] Parents and caregivers believe their children/wards may be unduly stigmatised, particularly if they are seen with any form of inhalation devices at home and in school. [60, 65] Aliyu, et al. [65] in Kano, northwest Nigeria in a survey of 119 caregivers of children with asthma attending a specialist clinic observed that two-thirds of them preferred oral medications for the treatment of their children/wards and $27.7 \%$ outrightly rejected metered-dose inhalers (MDI) prescription. [63] This aversion to inhalation device is based on various misconceptions including the fact that the use of MDI may make asthma "chronic". However, the authors of that study highlighted the important roles of counselling and asthma education as majority of the caregivers were willing to accept the use of inhalation device after appropriate counselling. [65] 
Poor symptoms perceptions by children and caregivers

The GINA criteria provide a quick and clinically relevant way of assessing symptoms control in childhood asthma care. [1] This involves the assessment of day time and night time symptoms, frequency of the use of reliever medications, limitation of activities and lung function assessment. [1] The level of symptoms control may not always be accurately assessed due to poor perception of symptoms by the parents and caregivers. [64-66] This may also affect severity assessment as well as control and stepwise management of childhood bronchial asthma.

\section{Poor inhalation techniques}

Most of the surveys assessing inhalational techniques of patients with asthma in Nigerian were conducted among adults with an unacceptably low prevalence rate of correct usage. $[67,68]$ Similar findings were reported in Kenya, ${ }^{[69]}$ where $55.0 \%$ of 82 children surveyed did not use the inhalation devices correctly. ${ }^{[69]}$ In a systematic review of various errors committed during the use of inhalational devices over 40 years, Sanchis, et al. [70] reported poor coordination, errors with speed and/or depth of inspiration and errors in post inspiration breath holds as the most frequent errors associated with the use of inhalation devices, especially the metered-dose inhalers.

\section{Healthcare providers-related challenges}

Inadequate knowledge and skills of the various cadres of health workers in Nigeria concerning the diagnosis and management of childhood bronchial asthma have been reported. [71-75] Suboptimal knowledge about the diagnosis and management of childhood bronchial asthma was reported among medical practitioners, [71] paediatric residents [72, 73] nurses [74] and pharmacists ${ }^{[75]}$ as well as among school teachers [61, 62] and parents/caregivers of children with bronchial asthma. [60, 65] Poor knowledge was reported by health care providers concerning the use of asthma-related facilities such as spirometers, peak flow meters, and inhalation devices including spacer devices and nebulisers. $[76,77]$ Sometimes these facilities are not even available. [78-80] It is even worrisome that the unavailability of basic facilities for optimal asthma care was reported from tertiary and secondary facilities in urban and semi-urban centres. The situation is worse among primary health care workers, particularly in the rural areas of the country.

Lack of awareness and adherence to National Guidelines

The national guidelines on the management of bronchial asthma are meant to guide asthma care professionals on the diagnosis, management, risk assessment, treatment of acute exacerbations, follow-up care and overall management of children with asthma. They are often local adaptations of global recommendations. Until recently, there was no national guideline for the management of asthma in Nigeria. [9] Experts believe that national guidelines should be implemented by asthma care professionals, particularly the prompt and adequate use of inhaled corticosteroids as controller medication, adequate risks assessment, management of comorbid conditions and triggers as well as optimal step-wise management of asthma. [1, 81] Unfortunately, the knowledge of asthma care physicians about asthma management guidelines was reported to be suboptimal. [44, 82] Therefore, routine training and re-training and appropriate implementation of the guidelines are advocated.

Lack of awareness about the latest development in the management of childhood asthma

The management of childhood bronchial asthma is a very dynamic field with frequent evidencebased updates and review. [1, 13] Asthma care professionals and health workers generally, are required to update their knowledge and skills 
about the disease and its management. Unfortunately, most practitioners in Nigeria are unaware of asthma treatment guidelines, appropriate asthma management steps and follow-up care of individuals with asthma. Also, attendance at routine update courses is very low among medical practitioners especially those in private practice. [71, 74-76]

Inadequate manpower and time to provide comprehensive asthma education to caregivers and patients

There is a paucity of health care professionals in Nigeria and other LMICs. This is made worse with increased waves of brain drain of health care workers to developed countries. [83] Also, asthma care professionals who specialised in the care of children are even in greater demand. The available ones are often overworked as they have to combine the roles of physicians, asthma nurse, asthma educator, lung function technician, and psychologists to offer holistic asthma care to children. Therefore, the paediatric asthma care physician may not have the time and patience to provide comprehensive asthma education to parents/caregivers, school teachers and children with asthma.

\section{Healthcare Facilities-related challenges}

Lack of facilities for diagnosis and monitoring of childhood asthma

Unavailability and unaffordability of appropriate facilities for precise asthma diagnosis and management are major challenges for asthma management. [5-59, 76-80] This had raised concerns about the ability of Nigerian asthma care professionals to meet global standards on the management of asthma in general and childhood asthma in particular. [80] Many centres, even tertiary care centres, do not have basic asthma care facilities such as spirometers, peak flow meters, facilities for an allergic skin test, fractional expired Nitric oxide (FeNO) measurement and methacholine challenge test. Facilities for appropriate characterising, endotyping and precision diagnosis of childhood asthma-like serum inflammatory cytokines assessment, and total and specific immunoglobulin (Ig) E estimation are also sparse. ${ }^{[76-79]}$ This has adversely affected the depth of diagnosis, severity assessment, monitoring and follow-up care of children with bronchial asthma.

The diagnostic challenge of preschool asthma

There is a wide variety of asthma mimics among preschool children in whom the prevalence of asthma is reportedly on the increase. Hospitalbased reports showed that preschool children constitute $20-40 \%$ of childhood asthma cases seen at the pulmonology clinics. [24-30] Bronchial asthma, in this age group, is easily underdiagnosed or over-diagnosed as conditions like foreign body aspiration, pulmonary tuberculosis, viral respiratory tract infections, adenoidal hypertrophy, bronchitis and bronchiolitis could be differential diagnoses of bronchial asthma. ${ }^{[10-12,85]}$ Unfortunately, objective assessment of reversible expiratory airway obstruction, is not easy in this age group as quality spirometry is difficult to get in them even with the use of incentives spirometry. ${ }^{[12]}$ Also, diagnostic facilities such as forced oscillation and interrupter techniques for lung function assessment in this age group are not readily available. Awareness of diagnostic criteria such as the asthma predictive index in preschool children is low among clinicians. [10] This constitutes a major challenge in the management of childhood asthma in Nigeria.

\section{Unavailability of controller medications}

Inhaled corticosteroids (ICS) are the bedrock of bronchial asthma management. Recent GINA recommendations strongly suggest the use of ICS either on daily purpose or even as required. [1] Chronic inflammation of the small airway is an important pathogenetic mechanism of bronchial asthma, hence the important role of antiinflammatory agents like ICS. [1] ICS alone is often 
not available and or affordable to Nigerian children. This is a major challenge to asthma care physicians and is, therefore, a major step back for optimal asthma care for childhood asthma in Nigeria.

Unavailability of child-friendly inhalational devices and spacer devices

Most children cannot use dry powder inhalers (DPI) as they do not often generate the required inspiratory force for optimal use of DPI. Even the pressurised MDI is very difficult to use optimally in children hence the importance of spacer device. [1, 12] Commercially available spacer devices with the antistatic wall are often not available and/or affordable in Nigeria and many LMICs. [86] This is an important challenge as the inappropriately used medication will lead to wastages, increased cost and poor symptom control. [12]

Poor health system

The Nigerian health system involves heterogeneous health care providers comprising public, private for-profit, community-based organisation ( $\mathrm{CBO})$, faith-based organisation (FBO), and traditional healthcare providers. [87] There is often little or no synergy among these providers, hence health care delivery is not synchronised and organised. Health care financing is mostly by direct (out-of-pocket) payment with very few proportions of the populace covered by any form of health insurance. [87, 88] This often leads to health financing catastrophe in a bid to meet health demands. ${ }^{[54,88]}$ The management of childhood asthma often impose a huge financial burden on the family particularly if the payment has to be done out-of-pocket and this often leads to seeking alternative medical care in unorthodox and substandard settings. [88]

\section{Possible solutions to the challenges}

Awareness creation
Creating awareness about bronchial asthma, particularly childhood asthma, may assist in addressing the challenges of ignorance. Different fora can be used and the school health programme is an important platform to achieve this. The school population is an accessible and willing population that can be used to spread the message not only within the schools but also beyond the walls of the school.

Capacity-building - training and re-training and need for more specialists in childhood asthma care

There is a need to train more asthma care professionals to meet the increasing demand for quality asthma care. Training and re-training of available professionals, [71-77] and prevention of brain drain will go a long way in addressing this challenge

Provision of facilities for diagnosis and monitoring Basic facilities for childhood asthma diagnosis, management and follow-up care should be made available at health facilities including the primary health care facilities in both urban and rural areas so that children will have access to the very basic but qualitative asthma care services.

\section{Locally adaptable guidelines}

This should be made available to all asthma care professionals and personnel at all levels of health care. Routine update and refresher courses should be organised for all cadre of medical personnel in public and private practice for optimal asthma care for Nigerian children.

Making appropriate inhalational and spacer devices available and affordable

Inhaled corticosteroids with appropriate childfriendly devices, which is the bedrock of childhood asthma management, should be made available and affordable to Nigerian children. Pharmaceutical companies with an interest in anti-asthmatics, regulatory authorities and health care providers should work in synergy to ensure the availability. Also, locally available 
alternatives can be standardised; for instance, the use of home-made plastic spacer devices was reported to be as effective as commercially produced but expensive patented ones in a South African study. ${ }^{[84]}$

\section{Health care financing}

The cost of childhood asthma is very huge and is beyond what individuals and family can afford if unsubsidised. Insurance coverage, to include care for children with asthma and other noncommunicable diseases, is hereby advocated. Also, the assistance of governmental and nongovernmental agencies, foundations and philanthropies to be involved in asthma care, particularly as related to Nigerian children.

\section{Research works on childhood asthma}

There is a paucity of research on childhood asthma in Nigeria to reflect the evolving pattern of prevalence. The available research on this important subject included limited studies from tertiary centres with little or no input from secondary and primary health care centres. More research works including operational and interventional researches are needed to overcome some of the challenges associated with the diagnosis and management of childhood asthma.

\section{Asthma support and Advocacy}

The formation of support and advocacy groups for childhood bronchial asthma are urgently required across the country. This will assist in defining the challenges peculiar to the various regions of the country and also serve as emotional and psychological relief to caregivers and children with asthma alike. Also, asthma care physicians and other professionals can interact and cross-fertilise ideas and advocate for improved asthma care for Nigerian children. School-based Parents/Caregivers Asthma Support Group, using the leverage of World Asthma Day celebration, should be formed nationwide for more childhood asthma information dissemination, awareness creation and support in the diagnosis and treatment.

\section{Conclusion}

This scoping review has highlighted the huge burden of childhood bronchial asthma in Nigeria with the enormous three-pronged pattern of challenges associated with the management of childhood asthma in a developing setting like Nigeria and also made a bold attempt to proffer solutions to these challenges.

Acknowledgement: The author is grateful to the members of the Asthma Support Group at the Wesley Guild Hospital, Ilesa, Nigeria, for their supports in the preparation of this review.

Conflict of Interest: None declared.

Funding: Self-funded.

Publication History: Submitted 23 April 2020; Accepted 16 September 2020.

\section{References}

1. Global Initiative for Asthma (GINA). Global Strategy for Asthma Management and Prevention - Burden Report. Geneva: Global Initiative for Asthma; 2020. Available from: http://www.ginasthma.com. Accessed on 18 Apr 2020.

2. Oviawe O. Asthma in Children. In: Azubuike JC, Nkaginieme KEO. (Editors) Paediatrics and Child Health in a Tropical Region. 2nd Edition. African Educational Service, Owerri, Nigeria. 2007. p. 460-468.

3. Asher MI, Montefort S, Björkstén B, Lai CK, Strachan DP, Weiland SK, et al. Worldwide time trends in the prevalence of symptoms of asthma, allergic rhinoconjunctivitis, and eczema in childhood: ISAAC Phases One and Three repeat multi-country cross-sectional 
surveys. Lancet 2006; 368: 733-743. doi:10.1016/S0140-6736(06)69283-0.

4. Weinberg, E G. Urbanization and childhood asthma: An African perspective. J Allergy Clin Immunol 2000; 105: 224-231. doi:10.1016/s0091-6749(00)90069-1.

5. Falade AG, Ige OM, Yussuf BO, Onadeko $\mathrm{MO}$, Onadeko BO. Trends in the prevalence of symptoms of asthma, allergic rhinoconjunctivitis and atopic eczema. J Natl Med Assoc 2009; 101: 414-420. doi.org/10.1016/S0027-9684(15)30925-1

6. Fuchs O, Von mutius E. Genetic and environmental factors in bronchial asthma and wheezing disorders. In: Ernst Eber E, Midulla F (Editors) ERS handbook Paediatric Respiratory Medicine. 1st Edition Sheffield, UK. 2013. p. 298-304.

7. Ober C, Hoffjan S. Asthma genetics 2006: the long and winding road to gene discovery. Genes Immun 2006; 7: 95-100. doi.org/10.1038/sj.gene.6364284.

8. Barnes PJ, Bush A. Biology and Assessment of Airway Inflammation. In: Wilmott RW, Boat TF, Bush A, Chernick V, Deterding RR, Ratjen FR (Editors), Kendig and Chernick's Disorders of the Respiratory Tract in Children. 8th edition. Philadelphia, PA, WB Saunders, 2012. p. 75-88.

9. Erhabor GE, Abdullahi AA, Ozoh OB, Adeniyi BA, Desalu OO, Falade AG, et al. Nigeria Asthma Management Guideline. IleIfe: Signet; 2017.

10. Martinez FD, Wright AL, Taussig LM, Holberg CJ, Halonen M, Morgan WJ. Asthma and wheezing in the first six years of life. The Group Health Medical Associates. N Engl J Med 1995; 332: 133-138. doi:10.1056/nejm199501193320301.

11. Castro-Rodriguez JA, Holberg $\mathrm{CH}$, Wright AL: A clinical index to define risk of asthma in young children with recurrent wheezing.
Am J Respir Crit Care 2000; 162: 1403-1406. doi:10.1164/ajrccm.162.4.9912111.

12. Pijnenburg $M$, Carlsen KCL. Bronchial asthma. In: Eber E, Midulla F (Editors) ERS handbook Paediatric Respiratory Medicine. 1st Edition Sheffield, UK 2013. p. 316-327.

13. Piacentini G, Tenero L. Emerging therapeutic strategies In: Eber E, Midulla F (Editors) ERS handbook Paediatric Respiratory Medicine. 1st Edition Sheffield, UK 2013. p. 328-332.

14. Akhiwu HO, Asani MO, Johnson AB, Ibrahim M. Epidemiology of pediatric asthma in a Nigerian population. J Health Res Rev 2017; 4: 130-136. doi:10.4103/jhrr.jhrr_114_16.

15. Ozoh OB, Aderibigbe SA, Ayuk AC, Desalu OO, Oridota OE, Olufemi O, et al. The prevalence of asthma and allergic rhinitis in Nigeria: A nationwide survey among children, adolescents and adults. PLoS ONE 2019; 14: e0222281. Available at: https://doi.org/10.1371/journal.pone.02222 81 Accessed 18 April 2020.

16. Thatcher JD, Emmelin A, Madaki AJK, Thatcher TD. Biomass fuel use and the risk of asthma in Nigerian children. Resp Med 2013; 107:

1845-1851. doi.org/10.1016/j.rmed.2013.09.009.

17. Falade AG, Olawuyi JF, Osinusi K, Onadeko BO. Prevalence and severity of symptoms of asthma, allergic rhinoconjunctivitis, and atopic eczema in 6- to 7-year-old Nigerian primary school children: The International Study of Asthma and Allergies in Childhood. Med Princ Pract 2004; 13: 20-25. doi:10.1159/000074046.

18. Onazi SO, Orogade AA, Yakubu AM. Exercise-Induced Bronchospasm among school children in Gusau, Nigeria. West Afr J Med 2012; 31: 76-80.

19. Ibe CC, Ele UP. Prevalence of bronchial asthma among adolescents in Anambra State, Nigeria. Niger J Int Med 2002; 5: 23-26. 
20. Kuti BP, Kuti DK, Mohammed LO, Omole KO, Minna YA, Oso BI. Prevalence and factors associated with exercise-induced bronchospasm among rural school children in Ilesa, Nigeria. Niger Postgrad Med J 2017; 24: 107-113. doi:10.4103/npmj.npmj_46_17.

21. Kuti BP, Kuti DK, Omole KO, Ologun BG, Minna YA, Oso BO, et al. Exercise-Induced Bronchospasm in Ilesa, Nigeria: A Comparative study of rural and urban school children. Niger J Health Sci 2017; 17: 25-34. doi:10.4103/njhs.njhs_7_17.

22. Oluwole O, Arinola GO, Huo D, Olopade CO. Household biomass fuel use, asthma symptoms severity, and asthma underdiagnosis in rural schoolchildren in Nigeria: a cross-sectional observational study. BMC Pulm Med 2017; 17: 3. doi:10.1186/s12890-016-0352-8.

23. Oluwole $\mathrm{O}$, Arinola GO, Falade AG, Ige MO, Falusi GA, Aderemi $\mathrm{T}$, et al. Allergy sensitisation and asthma among 13-14-year old school children in Nigeria. Afr Health Sci 2013; 13: 144-153. doi:10.4314/ahs.v13i1.20.

24. Ayuk AC, Eze JN, Edelu BO, Oguonu T. The prevalence of allergic diseases among children with asthma: What is the impact on asthma control in Southeast Nigeria? Niger J Clin Pract 2018; 21: 632-638. doi:10.4103/njcp.njcp_343_17.

25. Garba B, Sani U, Isezuo K, Waziri U, Ugege M, Adamu A, Jiya F. Pattern of allergic comorbidities in children with asthma in Sokoto, Northwestern Nigeria. Inter J Biomed Res 2019; 10: e5282. doi:10.7439/ijbr.v10i10.5282.

26. Odusote O, Akinda IJ, Ubuane PO, Ogunleye A, Dike G. Allergic co-morbidities in children with asthma in Lagos, Nigeria: A pilot crosssectional study. Proceedings of the ALLPAEDS 2018 Joint Conference of the South African Paediatric Association (SAPA) and The Allergy Society of South Africa (ALLSA). 2018.

27. Kuti BP, Omole KO. Epidemiology, triggers and severity of childhood asthma in Ilesa, Nigeria. Implication for prevention and control. Niger Med J 2017; 58: 13-20. doi:10.4103/0300-1652.218412.

28. Okoh BAN, Frank-Briggs AI. Childhood asthma: A clinical study in Southern Nigeria. The Niger Health J 2014; 14: 165-171.

29. Oviawe O, Osarogiagbon WO. Trend in asthma severity in steroid naive asthmatic children in Benin City, Nigeria. Niger J Clin Pract. 2013; 16: 371-374. doi:10.4103/11193077.113466 .

30. Garba BI, Ibrahim M, Johnson A-WBR. Sociodemographic and clinical characteristics of asthmatic children seen at Aminu Kano Teaching Hospital, Kano, Nigeria. Niger J Paediatr 2014; 41: 360-364. doi:10.4314/njp.v41i4.14.

31. Okoromah $\mathrm{CN}$, Oviawe $\mathrm{O}$. Is childhood asthma underdiagnosed and undertreated? Niger Postgrad Med J 2002; 9: 221-225.

32. Kuti BP. Asthma co-morbidities in Nigerian Children: Prevalence, risk factors and association with disease severity and symptoms control. The Pan Afri Med J 2020; 35: 91. doi:10.11604/pamj.2020.35.91.18470.

33. Tunde-Ayinmode MF. Children with bronchial asthma assessed for psychosocial problems in a teaching hospital in Nigeria. Afr Health Sci 2015; 15: 690-700. doi:10.4314/ahs.v15i2.49.

34. Neagu F. Hypovitaminosis D is very frequent but not associated with asthma control in a low-income pediatric population seen in an allergy and immunology clinic. J Allergy Clin Immunol 2012; 129: 1. doi.org/10.1016/j.jaci.2011.12.332. 
35. Gessner BD, Plotnik J, Muth PT. 25hydroxyvitamin D levels among healthy children in Alaska. Pediatrics 2003; 143: 434437. doi:10.1067/s0022-3476(03)00410-4.

36. Omole KO, Kuti BP, Oyelami OA, Adegbola AJ, Omole JO. Serum vitamin D profile of Nigerian children with asthma: Association with asthma severity and control. Pediatric Pulmonology 2018; 53: 544-551. doi:10.1002/ppul.23969.

37. Yeldu MH, Danjuma M, Sulaiman MA, Muhammad JN, Garba BI, Ibrahim Y, Buhari S. Serum vitamin D status and biochemical parameters of asthmatic children in Sokoto Metropolis, North-western Nigeria. Asian J Med Sci 2020; 11): 64-70. doi.org/10.3126/ajms.v11i2.26772.

38. Kuti BP, Kuti DK. Relationship between serum 25-hydroxyvitamin D and inflammatory cytokines in Nigerian children with asthma, J Asthma. 2020; 1-10 doi:10.1080/02770903.2020.1712726.

39. Jesenak M, Zelieskova M, Babusoikova E. Oxidative stress and bronchial asthma in children - causes or consequences? Front Pediatr 2017; 5: 162. doi:10.3389/fped.2017.00162.

40. Kuti BP., Kuti DK. Serum Zinc, Selenium and Total Antioxidant contents of Nigerian children with asthma: Association with disease severity and symptoms control. J Trop Paediatr 2020; 66: 395-402. doi.org/10.1093/tropej/fmz078.

41. Garba BI, Ibrahim M, Johnson AW, Yahaya IA. Plasma high sensitivity C - Reactive Protein level in children with asthma seen at the Aminu Kano Teaching Hospital Kano. Sub-Saharan Afr J Med 2014; 1: 148-152. doi:10.4103/2384-5147.138948.

42. Edelu BO, Eze JN, Ayuk AC, Oguonu T. Prevalence and pattern of asthma exacerbation in children seen at the University of Nigeria Teaching Hospital,
Enugu. Niger J Paediatr 2016; 43: 78-82. doi:10.4314/njp.v43i2.3.

43. Onubogu U.C, Owate, E. Pattern of acute asthma Seen in Children Emergency Department of the River State University Teaching Hospital, Port Harcourt Nigeria. Open J Respir Dis 2019; 9: 101-111. doi:10.4236/ojrd.2019.94009.

44. Fawibe AE, Onyedum CC, Sogaolu OM, Ajayi AO, Fasae AJ. Drug prescription pattern for asthma among Nigerian doctors in general practice: A cross-sectional survey. Ann Thorac Med 2012; 7: 78-83. doi:10.4103/1817-1737.94524.

45. Nduagubam OC. A Comparison of the academic performance and intelligence scores of Asthmatic and Non-asthmatic Primary School Pupils in Enugu State, Nigeria. Niger Med J 2019; 60: 1-8. doi:10.4103/nmj.nmj_1_19.

46. Gottfried MA. Evaluating the relationship between student attendance and achievement in urban elementary and middle schools: an instrumental variables approach. Am Educ Res J 2010; 47: 434-465. doi.org/10.3102/0002831209350494.

47. Koinis-Mitchell D, Kopel SJ, Farrow ML, McQuaid EL, Nassau JH. Asthma and academic performance in urban children. Ann Allergy Asthma Immunol 2019; 122: 471477.

https://doi.org/10.1016/j.anai.2019.02.030.

48. Ayuk AC, Oguonu T, Ikefuna AN, Ibe BC. Asthma control and quality of life in schoolage children in Enugu south-east, Nigeria. Niger Postgrad Med J 2014; 21: 160-164. doi:10.1016/s1526-0542(12)70050-7.

49. Ayuk AC, Oguonu T, Ikefuna AN, Ibe BC. Health-related quality of life in school-aged children with and without asthma in Enugu, South-East Nigeria. Niger J Paediatr 2013; 40: 364-369. doi:10.4314/njp.v40i4.3. 
50. Ahmed PA, Ulonnam CC, MohammedNafi'u R. Assessment of quality of life among children with bronchial asthma and their caregivers at the National Hospital Abuja, Nigeria. Niger J Paediatr 2016; 43: 88-94. doi:10.4314/njp.v43i2.5.

51. Vos T, Allen C, Arora M, Barber RM, Bhutta ZA, Brown A, et al. Global, regional, and national incidence, prevalence, and years lived with disability for 310 diseases and injuries, 1990-2015: a systematic analysis for the Global Burden of Disease Study 2015. Lancet 2016; 388: 1545-1602 doi:10.1016/S0140-6736(16)31678-6.

52. Ferreira de Magalhães M, Amaral R, Pereira AM, Sá-Sousa A, Azevedo I, Azevedo LF, et al. Cost of asthma in children: a nationwide, population based, cost-of-illness study. Pediatr Allergy Immunol 2017; 28: 683-691. doi:10.1111/pai.12772.

53. Ferrante G, La Grutta S. The Burden of Pediatric Asthma. Front Pediatr 2018; 6: 186. doi:10.3389/fped.2018.00186.

54. Ughasoro M, Eze JN, Ayuk AC, ObumnemeAnyim I, Akubuilo U, Oguonu T. Economic burden of childhood asthma in children attending a follow-up clinic in a resourcepoor setting of Southeast Nigeria. Paediatr Res Reviews 2020; In press. https://doi.org/10.1016/j.prrv.2020.01.001. Accessed April 18th 2020.

55. Perry R, Braileanu G, Palmer T, Stevens P. The Economic burden of pediatric asthma in the United States: Literature Review of Current Evidence. PharmacoEconomics 2019; 37: 155-167. doi:10.1007/s40273-018-0726-2.

56. Oviawe O. The contexts of death outside hospital among children attending the asthma clinic. Niger J Clin Pract. 2000; 3: 2225 .

57. The WHO report on world life expectancy. https://www.worldlifeexpectancy.com/Nig eria-asthma. Accessed 23 April 2020.
58. Onyedum CC, Ukwaja KN, Desalu OO, Ezeudo C. Challenges in the management of bronchial asthma among adults in Nigeria: A systematic review. Ann Med Health Sci Res 2013; 3: 324-329. doi:10.4103/21419248.117927.

59. Ahmed PA, Olomukoro CN, Ulonnam C, Ballong J. The burden of childhood asthma and its management as seen at the National Hospital Abuja. Arch Nig Med Med Sci 2011; 8: 9-17.

60. Kuti BP, Omole KO. Factors associated with Caregivers' knowledge about childhood asthma in Ilesa, Nigeria. Annal Niger Med 2016; 10: 30-36. doi:10.4103/03313131.180806.

61. Adeyeye OO, Kuyinu YA, Ozoh OB. Assessment of the knowledge of teachers about asthma and the availability of facilities for asthma care in public secondary schools in Lagos, Nigeria. Afr J Thoracic Crit Care Med 2018; 24: 76-81. doi:10.7196/SARJ.2018.v24i2.192.

62. Kuti BP, Kuti DK, Omole KO, Oso BO, Mohammed LO, Minna YA. How much do school teachers know about Childhood Asthma in Ilesa, Nigeria? Niger J Paediatr 2017; $\quad 44: \quad 68-74$. http://dx.doi.org/10.4314/njp.v44i2.5.

63. World Health Organization. "What Is a Health System?" Geneva: World Health Organization, 2005. http://www.who.int/features/qa/28/en/in dex.html. Accessed 04 April 2020.

64. Kuti BP, Omole KO, Kuti DK. Factors associated with childhood asthma control in a resource-poor centre. J Fam Med Pri Care 2017; 6: 222-230. doi:10.4103/jfmpc.jfmpc_271_16.

65. Aliyu I, Asani MO, Peter ID, Michael GC. The perception of asthma and views on Metereddose Inhaler by caregivers of asthmatic 
children in Aminu Kano Teaching Hospital, Kano. Med J DY Patil Vidyapeeth 2018; 11: 3337. doi:10.4103/mjdrdypu.mjdrdypu_168_17.

66. Yoos HL, Kitzman H, McMullen A, Sidora K. Symptom perception in childhood asthma: How accurate are children and their parents? J Asthma 2003; 40: 27-39. doi:10.1081/jas120017204.

67. Onyedum CC, Desalu OO, Nwosu NI, Chukwuka CJ, Ukwaja KN, Ezeudo C. Evaluation of inhaler techniques among asthma patients seen in Nigeria: An observational cross-sectional study. Ann Med Health Sci Res 2014; 4: 67-73. doi:10.4103/2141-9248.126617.

68. Adeyeye OO, Onadeko BO. Understanding medication and use of drug delivery device by asthmatics in Lagos. West Afr J Med 2008; 27: 155-159.

69. Machira EPM, Obimbo EM, Wamalwa D, Gachare LN. Assessment of inhalation technique among asthmatic children and their carers at the Kenyatta National Hospital, Kenya. Afr J Resp Med 2011; 7: 19-22.

70. Sanchis J, Gich I, Pedersen S. Systematic Review of Errors in Inhaler Use: Has Patient Technique Improved Over Time? Chest 2016; 150: 394-406. doi:10.1016/j.chest.2016.03.041.

71. Osarogiagbon WO, Nwaneri DU, Oviawe O. Asthma management by medical practitioners: the situation in a developing country. World J Pediatr 2013; 9: 64-67 doi:10.1007/s12519-012-0389-6.

72. Ayuk A, Iloh K, Obumneme-Anyim I, Ilechukwu G, Oguonu T. Practice of asthma management among doctors in south-east Nigeria. Afr J Respir Med 2010; 3; 14-17.

73. Adeyeye OO, Kuyinu YA, Bamisile RT, Oghama CI. A preliminary assessment of nurses' asthma education needs and the effect of a training programme in an urban tertiary healthcare facility Afr J Respir Med 2015; 10: 13-17.

74. Osarogiagbon WO, Nwaneri DU, Oviawe O. Over-diagnosis of childhood asthma by medical residents: Who is to blame? Kanem J Med Sci 2010; 4: 38-41.

75. Ozoh OB, Omogie H, Obaseki DO, Dosu AO. The competence of community pharmacists in Lagos, Nigeria, on correct inhaler techniques. J Clin Sci 2018; 15: 207-12. doi: 10.4103/jcls.jcls_42_18

76. Adeniyi BO, Adebayo AM, Ilesanmi OS, Obaseki DO, Akinwalere OO, Erhabor GE. Knowledge of spacer device, peak flow meter and inhaler technique (MDIs) among health care providers: an evaluation of doctors and nurses. Ghana Med J 2018; 52: 15-21. http://dx.doi.org/10.4314/gmj.v52i1.4.

77. Desalu OO, Busari OA, Onyedum CC, Salawu FK, Obateru OA, Nwogu KC, et al. Evaluation of current knowledge, awareness and practice of spirometry among hospitalbased Nigerian doctors. BMC Pulm Med 2009; 9: 50.http://doi.org/10.1186/14712466-9-50.

78. Adeyeye OO, Bamisile RT, Brodie-Mends AT, Adekoya AO, Bolarinwa FF, Onadeko BO, et al. Five-year audit of spirometry at the LASUTH, Ikeja, south-west Nigeria. Afr J Respir Med 2012; 8: 15-17.

79. Desalu OO, Salami AK, Fawibe AE, Oluboyo PO. An audit of spirometry at the University of Ilorin Teaching Hospital, Ilorin, Nigeria (2002-2009). Ann Afr Med 2010; 9: 147-151. doi:10.4103/1596-3519.68365.

80. Desalu OO, Onyedum CC, Iseh KR, Salawu FK, Salami AK. Asthma in Nigeria: Are the facilities and resources available to support internationally endorsed standards of care? Health Policy 2011; 99: 250-254. doi:10.1016/j.healthpol.2010.10.006. 
81. Bush A. Welcome new guidelines: Now the hard work starts! Ann Thorac Med 2019; 14: 1-2. doi:10.4103/atm.ATM_338_18.

82. Chima EI, Iroezindu MO, Uchenna NR, Mbata GO, Okwuonu CG. A survey of asthma management practices and implementation of Global Initiative for Asthma guidelines among doctors in a resource-limited setting in Nigeria. Niger J Clin Pract 2017; 20: 984-991. doi:10.4103/njcp.njcp_88_16.

83. Martineau T, Decker K, Bundred P. "Brain drain" of health professionals: from rhetoric to responsible action. Health Policy 2004; 70: 1-10. doi:10.1016/j.healthpol.2004.01.006.

84. Ewa AU, Akpan F, Ntia HU, Okoi-Obuli J. The challenges of diagnosing bronchial asthma in very young infants in Calabar, Nigeria. Int J Contemp Pediatr 2015; 2: 450- 453.http:/ / dx.doi.org/10.18203/2349-

3291.ijcp20150992.

85. Zar HJ, Streun S, Levin M, Weinberg EG, Swingler GH. Randomised controlled trial of the efficacy of a metered-dose inhaler with bottle spacer for bronchodilator treatment in acute lower airway obstruction. Arch Dis Child 2007; 92: 142-146. doi:10.1136/adc.2006.101642.

86. Welcome MO. The Nigerian health care system: Need for integrating adequate medical intelligence and surveillance systems. J Pharm Bioallied Sci 2011; 3: 470478. doi:10.4103/0975-7408.90100.

87. Onyedum CC, Desalu OO, Ukwaja KN, Chukwuka C, Nwosu NI, Ezeudo C. Out-ofpocket costs of asthma follow-up care in adults in a Sub-Saharan African country. J Resp Med 2014; Article ID 768378. doi:10.1155/2014/768378.

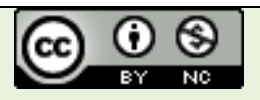

This is an Open Access document licensed for distribution under the terms and conditions of the Creative Commons Attribution License (http://creativecommons.org/licenses/by-nc/4.0). This permits unrestricted, non-commercial use, reproduction and distribution in any medium provided the original source is adequately cited and credited. 